\title{
Family Empowerment Model in Stunting Prevention Based on Family Centered Nursing
}

\author{
Luluk Fauziyah Januarti*, Alvin Abdillah, Agus Priyanto \\ STIKes Ngudia Husada Madura, Indonesia \\ *lulukfauziyah127@gmail.com
}

\begin{abstract}
Stunting is a global incidence with chronic malnutrition caused by a lack of nutritional intake in the past and conditions of failure to achieve physical development as measured by height for age, stunting problems especially those that occured in toddlerhood can result in motor developmental delays and decreased intelligence levels The purpose of this study is to determine the family empowerment model in preventing stunting based on family centered nursing. This study used an explanative survey design followed by descriptive study of the cross sectional approach, which was carried out with 2 stages. The first stage of the study was conducted by identifying internal and external factors for stunting prevention with family empowerment. The second stage involves conducting Focus Group Discussion (FGD) and expert discussion then devised a model of family empowerment as a stunting prevention effort. The number of respondents used was 280 families. The sampling techniques was using cluster sampling. The strongest indirectly data which obtained from the research analysis of the pathway to prevent stunting was extenal factors through stunting empowerment with value of 0.264 . The second strongest indirect influence was for stunting prevention through internal stunting prevention factors with value of 0.114 . The results of this study showed that the indirect influence of family empowerment on stunting prevention is not as strong as the direct influence. Family empowerment based on a family-centered nursing model can improve in the prevention of toddler stunting. Further research needs to develop family empowerment interventions that focus on specific efforts to increase fathers' participation in family centered nurse-based family empowermet programs related to child protection against stunting.
\end{abstract}

Keywords: Family Empowerment, Stunting Prevention, Family Centered Nursing 


\section{STRADA Jurnal Ilmiah Kesehatan}

DOI: $10.30994 /$ sjik.v9i2.536

ISSN: 2252-3847 (print); 2614-350X (online)

Vol.9 No.2 November 2020 Page.1797-1806

\section{BACKGROUND}

Stunting is an incidence that occurs globally, stunting problems especially that occured in toddlers age are taken seriously because it can result in motor developmental delays and decreased intelligence levels. The short-term impacts of malnutrition cases are that children become apathetic, speech disorders and other developmental disorders, while the long-term impacts are a decrease in IQ scores, decrease cognitive development, impair concentration, and decrease self-confidence, risk of obesity, glucose tolerance, coronary heart disease, hypertension, osteoporosis, decrease perfoma and productivity.

Based on data from the Ministry of Health (2013), there are 100 regencies in Indonesia that have quite high stunting rates, 11 of which are in East Java. East Java Province's Nutrition Status Monitoring (PSG) data in 2015 showed the prevalence of stunting in Bangkalan is the highest in East Java, which was $53.2 \%$ with detailed of the prevalence of very short toddlers at $27.4 \%$ and $25.8 \%$ of short toddlers (Dinas Kesehatan Bangkalan, 2015).

Prevention of stunting can be done by providing nutrition education to families of toddlers, which is one of Unicef's recommendations to alleviate stunting problems in Indonesia.Families with problems whose family membersexperience illness or disease often make the family unable to meet health care needs or in other terms experience poor health which resulting in worsening health condition of family members who have health problems. Family empowerment intervention is one of the interactive interventions that can be used to help families form the family empowerment process.

\section{METHODS}

\section{Study design}

This study used an explanative survey research design followed by a descriptive study of the cross-sectional approach conducted with 2 stages. The first stage of the study was conducted by identifying internal and external factors for stunting prevention with family empowerment with family-based centered nursing. The second stage is done by conducting Focus Group Discussion (FGD) and expert discussion then devised a model of family empowerment as a stunting prevention effort.

\section{Respondents}

The target population in this study were families with toddlers aged (1-5 years) in 18 subdistricts in Bangkalan Regency. The research sample is families who have a toddler in Bangkalan Regency. The sampling technique used cluster sampling where population members are grouped by region or location of the population. Sampling by means of cluster sampling is done based on the assumption that the characteristics of the subjects in each region are the same. In cluster sampling, the sampling unit is a hamlet in the subdistricts/villages.

\section{Instrument}

The distribution of questionnaires was conducted directly, and the questionnaires were submitted to respondents by researchers. The questionnaire is divided into 4 (four) namely: Questionnaire 1: Part A to identify internal and external factors of family empowerment. Questionnaire 2 : Part B to identify family empowerment. Questionnaire 3: Part D to identify stunting prevention efforts. WHO 2005 : Characteristic of the incidence of stunting toddlers to be studied was stunting with a history of birth body length $<48$ centimeters, history of breastfeeding and complementary foods of breast milk, history of low birth 


\section{STRADA Jurnal Ilmiah Kesehatan}

DOI: $10.30994 /$ sjik.v9i2.536

ISSN: 2252-3847 (print); 2614-350X (online)

Vol.9 No.2 November 2020 Page.1797-1806

weight, risk factors of stunting include infectious diseases, health services, immunizations, maternal knowledge, family income, family food availability, and environmental sanitation. Prevention of stunting through increasing family empowerment related to the prevention of infectious diseases, utilizing the yard as a source of family nutrition and improving environmental sanitation.

\section{Data Collection}

First, Submit the informed concent sheet, make an approach to families who have toddlers, submit a research measuring instrument (questionnaire). Then explain how to fill out the questionnaire. The dissemination of questionnaires was conducted directly, and the submission of questionnaires to respondents by researchers. Double-check the completeness of the data/questionnaire. Conducting data recapitulation, performing analysis and connecting between variables to conduct data analysis with Structural Equation Modelling (SEM), obtained strategic issues and basic solutions for recommendations in devising stunting prevention models. The second stage conducts focus group discussion as well as expert discussion, and the result will serves as a reference in the preparation of modules.

\section{Ethical considerations}

Prior to data collection, respondents were given informed consent that demonstrate the purpose of the research, the potential benefits and dangers of research, ensuring their complete anonymity during the study and that they had the freedom to withdraw from the research at any time. After the distribution of informed consent, respondents are required to sign an agreement indicating the respondent's voluntary decision to be part of the study. Researchers discuss issues such as confidentiality, anonymity and privacy. Then, the completed questionnaire is stored in a safe place and will be scorched or burned after 2 years.

\section{RESULT}

The results of family empowerment model in prevention of toddlers stunting in Bangkalan regency with 280 respondents conducted in June - August 2020. The discussion began with general data that included descriptions of the characteristics of research respondents as well as specific data which included frequency distribution, significance test results and statistical test research results

Table 1. Respondent Characteristics

\begin{tabular}{lll}
\hline Characteristics & Frequency & Percentage $(\%)$ \\
\hline Age & & \\
$15-19$ years old & 4 & 1,4 \\
20 - 35 years old & 230 & 82,0 \\
36 - 45 years old & 46 & 16,4 \\
\hline Total & 280 & 100.0 \\
\hline Job & & \\
Household assistant & 4 & 1,4 \\
The farmer & 44 & 15,7 \\
Housewives & 197 & 70,4 \\
Teacher & 18 & 6,4 \\
Government employees & 17 & 6,1 \\
\hline
\end{tabular}




\section{STRADA Jurnal Ilmiah Kesehatan}

DOI: $10.30994 /$ sjik.v9i2.536

ISSN: 2252-3847 (print); 2614-350X (online)

Vol.9 No.2 November 2020 Page.1797-1806

\begin{tabular}{lll}
\hline Characteristics & Frequency & Percentage (\%) \\
\hline Total & 280 & 100.0 \\
\hline Age & & \\
$12-23$ months & 126 & 45,0 \\
$24-35$ months & 76 & 30,4 \\
$36-47$ months & 67 & 23,9 \\
$48-59$ months & 11 & 3,9 \\
\hline Total & 230 & 100,0 \\
\hline Gender & & \\
Male & 143 & 50,9 \\
Female & 137 & 49,1 \\
\hline Amount & 280 & 100,0 \\
\hline
\end{tabular}

Table 1 explains that the age group of mothers who were the most respondents was 2035 years old and greater than other maternal age groups where this age is a good productive age and able to make their own decisions. Almost of the total respondents became housewives, because society assumes women are only at home while husbands make a living. The age group of children who were the most respondents was 12-23 months, which was older than the other child's age group. More than half of the total respondents were male.

Table 2. Coefficient Value

\begin{tabular}{llllll}
\hline No & Causality Relationship & & Coefficient & T-Statistical & Correlation \\
\hline 1 & $\begin{array}{l}\left(\mathrm{X}_{1}\right) \text { Internal Factors } \\
\left(\mathrm{Y}_{1}\right) \text { Family empowerment }\end{array}$ & $\rightarrow$ & 1,000 & 7,234 & Significant \\
\hline 2 & $\begin{array}{l}\left(\mathrm{X}_{2}\right) \text { External Factors } \\
\left(\mathrm{Y}_{1}\right) \text { Family empowerment }\end{array}$ & $\rightarrow 1,000$ & 15,872 & Significant \\
\hline 3 & $\begin{array}{l}\left(\mathrm{Y}_{1}\right) \text { Family empowerment } \\
\left(\mathrm{Y}_{2}\right) \text { Stunting Prevention }\end{array}$ & $\rightarrow 1,000$ & 14,230 & Significant \\
\hline
\end{tabular}

Table 2 explains that each exogenous variable is an External Factor that significantly affects endogenous variables namely family empowerment, stunting prevention. 


\section{STRADA Jurnal Ilmiah Kesehatan}

DOI: $10.30994 /$ sjik.v9i2.536

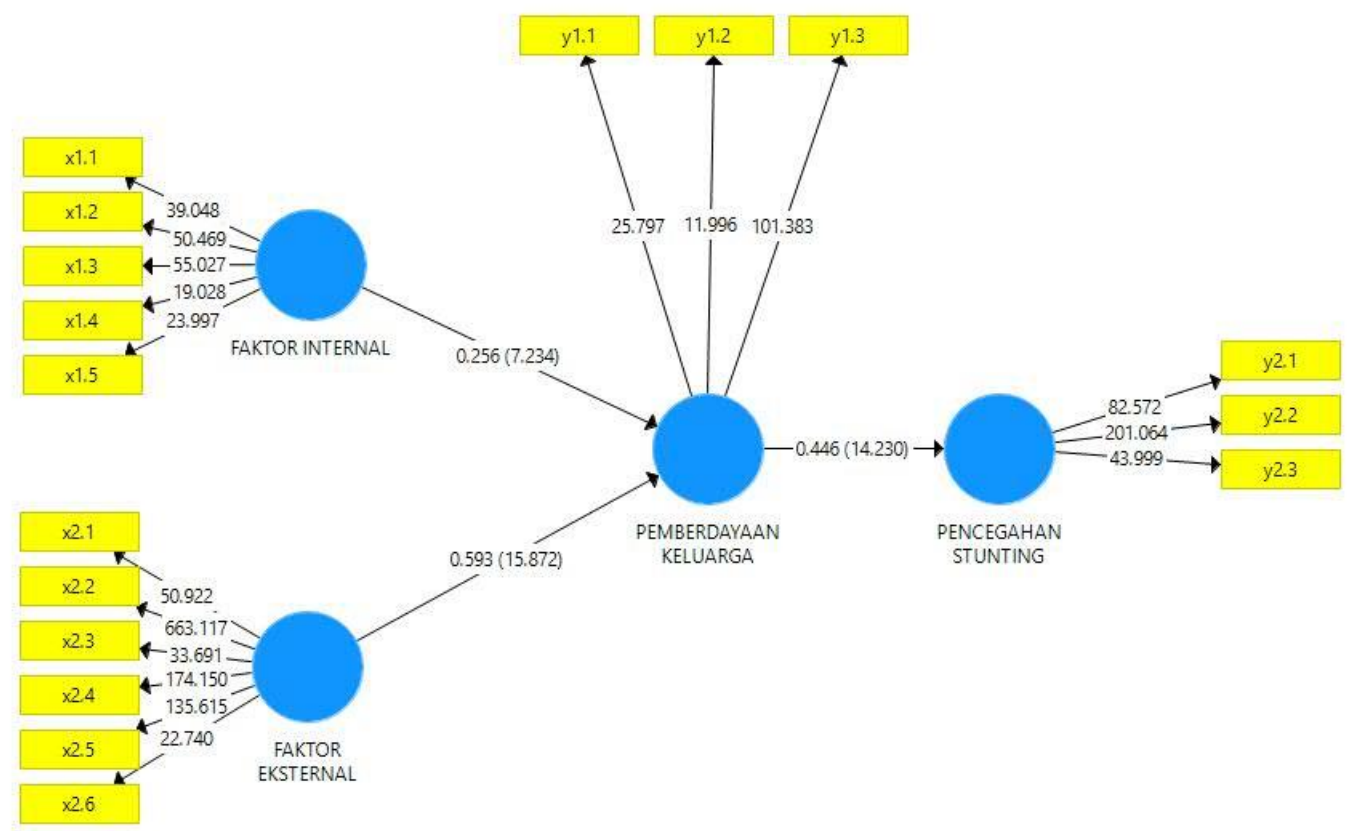

Figure 1. Model Structural

External factors have direct influence on internal factors of family empowerment, external factors are stimulus factors from outside a person (external factors). External factors or stimuli are environmental factors, both physical and non-physical environments in the form of socio-cultures, economics, politics, kinship, education, cultural values, technology, and so on. The biggest external factors in shaping human behaviors are the social and cultural factors where the person is located. External factors have significant influence on family empowerment in the preventing of stunting that carried out by families. The results of the T-test score on the analysis of structural models, where the T-rated factor of 17,992 showed that the role of culture and social structure (the role of family kinship, the value of technological culture, and political role) together had an effect on family self-reliance. This is because, Madurese families with cultural peculiarities that have existed for generations. However, there are several indicators that affect family empowerment, namely the family economy and the status of maternal education, because with these indicators people can provide nutritious food even though the food does not vary.

Family empowerment affects the family's stunting precautions. This is based on the Ttest score test on structural model analysis, where the T-value factor is 14,230. From 280 families, it was found that almost all of them was in moderate empowerment category.

\section{DISCUSSION}

Bangkalan community in carrying out stunting prevention is in the sufficient category. Based on the results of the questionnaire analysis, the parameters utilizing Bangkalan public health services to be able to bring sick children or families to the nearest health service. For health-improvement parameters, the public only receives information from health officials without the initiative to seek information related to family nutrition health. Meanwhile promotive, preventive, and rehabilitative parameters of the community have already applied healthy life such as washing hands before eating and able choose and consume fresh food. 


\section{STRADA Jurnal Ilmiah Kesehatan}

DOI: $10.30994 /$ sjik.v9i2.536

ISSN: 2252-3847 (print); 2614-350X (online)

Vol.9 No.2 November 2020 Page.1797-1806

Family empowerment is a condition in which one is not depended on others in making decisions and the presecence of self-confidence (Friedman, Bowden, \& Jones, 2010). The family can be formed from an independent family. Family independence is divided into four levels: the family receives health care officers, the community and receives the nursing services provided according to the nursing plan, the family knows and can express health problems correctly, performs simple nursing action as recommended and utilizes health care facilities, provides preventive measures according to the recommendations and actively promote actions of the Ministry of Health (2013). With family independence in caring for sick family members, it will make the family ready to help others family members when sick.

The results of research conducted by Aswadi, Syahrir, \& Adha (2018) obtained that nutrition education three times per week in integrated service post (Pos Pelayanan Terpadu/Posyandu) can improve the knowledge score and feeding practice of stunting toddlers. Maternal nutrition knowledge is one of the factors that has a significant influence on stunting incidence.

Families as an individual group in a family that can cause, prevent, ignore, or improve individual health problems in the family from beginning to end will be affected by the family (Priastana, Haryanto, \& Suprajitno, 2018). Family plays an important role in all forms of prevention (Friedman et al., 2010). Prevention that can be done by families against stunting in children in the family based on Caplan \& Holland (1990) in the concept of public health models includes: 1) primary prevention through health promotion and special protection; 2) secondary prevention includes early diagnosis with health screening; 3) Tertiary prevention includes hospital services (diagnosis and treatment) for rehabilitation and preventing complications. Primary prevention is to teach a good 4 healthy 5 perfect diet to the family, advising to provide exclusive breastfeeding without any complementary food until the child is 1 year old and providing complete immunization to the children. Secondary prevention is to encourage family members (children) to do health screening / early detection such as monitoring the growth and development of the children, actively participating in integrated service post activities, while tertiary prevention is by ingesting family members (children) to the health care facility if they complain of illness and deciding to be treated in the hospital and need to be hospitalized for futher treatment.

Utilization of health services is access or affordability of children and families as an efforts to prevent disease and health care such as immunization, pregnancy checks, delivery assistance, weighing children, health and nutrition education, as well as good health facilities such as integrated services post (posyandu), public health center (pusat kesehatan masyarakat/puskesmas), midwife or doctor practices, hospitals and clean water supplies. The inaccessibility of health services (because they are far away and/or unable to pay), lack of education and knowledge are obstacles for the community and families to maximaze the usage of the available health services. This can also have an impact on a child's growth (Kullu, Yasnani, \& Lestari, 2018).

Kullu et al. (2018) said that the health of the child should be taken care of by parents by immediately bringing their sick child to the nearest health care service in order to be treated immediately, because repeated infectious diseases can increase the risk of stunting in children. Not only that, the utilization of health services when a child was still in the womb until the child was born also needs to get attention, such as pregnancy screening as well as maternal visits to posyandu or other health services to check and provide complete immunizations to their children which can affect the growth of a child, because the use of good health services not only lowers morbidity rate in children and pregnant women but can 


\section{STRADA Jurnal Ilmiah Kesehatan}

DOI: $10.30994 /$ sjik.v9i2.536

ISSN: 2252-3847 (print); 2614-350X (online)

Vol.9 No.2 November 2020 Page.1797-1806

also increase a mother's knowledge to prevent her child from having infectious diseases and malnutrition that can lead to stunting in the child.

Body hygiene, food and the environment play an important role in maintaining health and preventing diseases. One clean habit, such as washing hands with soap before eating and after defecating, has become the focus of WHO campaign to reduce the incidence of disease. It has been proven that washing hands with clean water and soap can reduce the incidence of disease by $42-47 \%$. Environmental quality especially the availability of clean water, sanitation facilities, healthy living habits such as washing hand habits with soap, defecating in latrines and so on need to get attention, this is necessary because self-hygiene and a good environment can reduce the risk of infectious diseases that can affect the growth of a child (Sismulyanto et al., 2017).

To prevent an increase of stunting prevalence, it is necessary to start an early treatment, such as the need to monitor the growth of toddlers with regular height measurements through posyandu, as well as regular health counseling in improving nutritional knowledge for parents, especially maternal knowledge so that knowldge increases in order to create a family that is aware of nutrition.

Family is a resource to create healthy behaviors for each member because the family is the first institution to build human resources. In the family the main activity of an individual's life takes place so that the functioning of the family will determine the quality of the individual. Families play a role in establishing cultural norms (Setiawan, Machmud, \& Masrul, 2018).

Kaur \& Singh (2013)explained that the family environment emerged as a significant predictor of child environmental control. Public Health Model Prevention Theory (Caplan \& Holland, 1990) described effective interpersonal relationships, improving tasks that match to the age groups, developing control capabilities in groups. The impact is the ability of individuals to make decisions. So that families are not easily affected by local habits that can harm the development and growth of children such as providing breast milk companion food (makanan pendamping ASI/MP-ASI) before the age of 6 months. Family in theory Family Centered Nursing is the most significant source of support and assistance in helping other family members lifestyles changing (Friedman et al., 2010; Reyes et al., 2004).

In accompanying the child's development, the family's ability to maintain and preserve a culture, adapt to a culture that does not harm or reorganize the family culture can improve the family's ability to prevent stunting. The family is a role model to adopt to the local cultural tradition in order to be able to make decisions in providing action for the development and growth of children to prevent stunting. So the better prevention done by families with a cultural approach, the better the prevention of stunting carried out by families.

Stunting prevention has a significant effect on the incidence of stunting by families. It is obtained that almost the whole family has self-reliance in the category of sufficient. As evidenced by the family taking precautions to minimize the prevalence of stunting incidence rates. The results of the analysis of stunting prevention questionnaires by the family obtained the highest score for the question of Culture Care Rescructuring Tertiary Prevention in the category of sufficient with the statement almost all families consulted to health workers actively related to stunting prevention and did not ignore the recommendations that health officials recommended in terms of nutritional fulfillment of toddlers to prevent stunting. This indicates that most families take precautions when already in a state of illness or at a degree of tertiary prevention (Habimana \& Biracyaza, 2019; Meutia \& Yulianti, 2019). 


\section{STRADA Jurnal Ilmiah Kesehatan}

DOI: $10.30994 /$ sjik.v9i2.536

ISSN: 2252-3847 (print); 2614-350X (online)

Vol.9 No.2 November 2020 Page.1797-1806

Families who play an active role in performing stunting precautions will be able to minimize stunting incidence. Actively carrying out initial examination to identify the signs of stunting by consulting with a health professional, will be able to perform stunting prevention properly. The family will be informed regarding what should be given and avoided by them so that the child does not fall in a stunted condition. In addition, by not ignoring the recommendations in fulfillment of nutrition by providing good nutrition to children, consisting of fruit, vegetables and side dishes. Provide a variety of foods that are able to increase the child's appetite and not delay when giving food intake to the child.

Family Centered Nursing Theory, the function of health care and maintenance is a function of maintaining the health state of family members in order to maintain high productivity. These functions relate to the role of the family in caring for the sick family members. Families as individual group in the family can cause, prevent, ignore, or improve individual health problems in the family from beginning to end will be affected by the family. Family plays an important role in all forms of prevention (Friedman et al., 2010).

Stunting is the condition of infants who fail to grow at the age of 0-11 months and toddlers aged 12-59 months. The occurrence of stunting is a result of chronic malnutrition especially in the first 1,000 days of life, so that the child is too short for their age. Lack of nutrition usually occured since the babies are still in the womb and at the beginning after the baby was born, but for stunting conditions are only seen after the child is 2 years old (Ramayulis, 2018). Kaur \& Singh (2013) explained that the family environment emerged as a significant predictor of control in the child environment. Public Health Model Prevention Theory describes effective interpersonal relationships, improving tasks that match age groups, developing control capabilities in groups. The impact is the ability of individuals to make decisions. So that families are not easily affected by local community that can harm the development and growth of children such as providing breast milk companion food (MPASI) before the age of 6 months. Family is the most significant source of support and assistance in helping other family members change lifestyles (Friedman et al., 2010).

In accompanying the child's development, the family's ability to maintain and preserve a culture, adapt to a culture that does not harm or reorganize the family culture can improve the family's ability to prevent stunting. The family is a role model to adopt to the local cultural tradition in order to be able to make decisions in providing action for the development and growth of children to prevent stunting. So the better prevention done by families with a cultural approach, the better the prevention of stunting carried out by families (Januarti \& Hidayathillah, 2020).

To prevent the increasing of stunting prevalence, it is necessary to start treatment from an early age, such as the need to monitor the growth of toddlers with regular height measurements through posyandu, as well as the need for regular health counseling in improving nutritional knowledge for parents, especially maternal knowledge in order to increas the knowledge to generate a family that is aware of nutrition (Santoso et al., 2019).

According to UNICEF and WHO stunting problems in toddlers can hinder child development, with negative impacts that will take place in later life such as intellectual decline, susceptibility to non-contagious diseases, decreased productivity to lead to poverty. It was stated in the Decree of the Ministry of Health that the health promotion is an effort to improve the ability of the community through learning from, by, for, and with the community, which can develop community resource activities according to local sociocultural conditions (Kementerian Kesehatan RI, 2013).

It is known that family prevention assessed from Culture care preservation, Culture care accommodation, and Culture Care Rescructuring found that family prevention is part of the 


\section{STRADA Jurnal Ilmiah Kesehatan}

DOI: $10.30994 /$ sjik.v9i2.536

ISSN: 2252-3847 (print); 2614-350X (online)

Vol.9 No.2 November 2020 Page.1797-1806

family prevention pattern, good enough with Culture care preservation, Culture care accommodation, and Culture Care Rescructuring is effective to prevent stunting incidence (Leininger \& McFarland, 2002).

\section{CONCLUSION}

Family empowerment affects the family's stunting precautions. Family empowerment is a condition in which one does not depend on others in making decisions and the presence of confident attitude. The family empowerment can be formed from an independent family. The results of the most powerful indirect stunting prevention pathway analysis are extenal factors through stunting empowerment. The second strongest indirect influence is for the prevention of stunting through internal factors of stunting prevention. The results of this study showed that the indirect influence in the family empowerment on the prevention of stunting is not stronger than the direct influence.

\section{REFERENCES}

Aswadi, Syahrir, S., \& Adha, A. S. (2018). Perilaku Ibu Terhadap Pemanfaatan Posyandu Balita Di Wilayah Kerja Puskesmas Tarakan Kecamatan Wajo Kota Makassar. AlSihah: Public Health Science Journal, 10(1), 12-25.

Caplan, R., \& Holland, R. (1990). Rethinking health education theory. Health Education Journal, 49(1), 10-12. https://doi.org/10.1177/001789699004900103

Dinas Kesehatan Bangkalan. (2015). Profil Kesehatan Kabupaten Bangkalan. Bangkalan.

Friedman, M. M., Bowden, V. R., \& Jones, E. G. (2010). Buku Ajar Keperawatan Keluarga : Riset, Teori, \& Praktik (5th ed.). Jakarta: EGC.

Habimana, S., \& Biracyaza, E. (2019). Risk Factors Of Stunting Among Children Under 5 Years Of Age In The Eastern And Western Provinces Of Rwanda: Analysis Of Rwanda Demographic And Health Survey 2014/2015. Pediatric Health, Medicine and Therapeutics, Volume 10, 115-130. https://doi.org/10.2147/PHMT.S222198

Januarti, L. F., \& Hidayathillah, A. P. (2020). Parenting Culture on The Role of Father in Prevention of Stunting in Toddler. Babali Nursing Research, 1(2), 81-90. https://doi.org/10.37363/bnr.2020.1211

Kaur, J., \& Singh, D. (2013). Family Environment as a Predictor of Psychological Hardiness among Adolescents. Indian Journal of Positive Psychology, 4(3).

Kementerian Kesehatan RI. (2013). Pedoman Teknis Pemberian Makan Bayi dan Anak. In Riset Kesehatan Dasar. Jakarta: Badan Penelitian dan Pengembangan Kementerian Kesehatan Republik Indonesia.

Kullu, V. M., Yasnani, \& Lestari, H. (2018). Faktor-Faktor yang Berhubungan dengan Kejadian Stunting pada Balita Usia 24-59 Bulan di Desa Wawatu Kecamatan Moramo Utara Kabupaten Konawe Selatan Tahun 2017. JIMKESMAS, 3(2), 1-11.

Leininger, M., \& McFarland, M. (2002). Transcultural nursing: Concepts, theories, research, and practice (3rd ed.). New York: McGraw-Hill.

Meutia, I. F., \& Yulianti, D. (2019). Stunting Intervension Strategy Based on Community Empowerment. Jurnal Kesehatan Masyarakat, 15(2), 187-195. https://doi.org/10.15294/kemas.v15i2.19049

Priastana, I. K. A., Haryanto, J., \& Suprajitno, S. (2018). Peran Dukungan Sosial Keluarga terhadap Berduka Kronis pada Lansia yang Mengalami Kehilangan Pasangan dalam Budaya Pakurenan. Indonesian Journal of Health Research. https://doi.org/10.32805/ijhr.2018.1.1.8

Ramayulis, Rita. (2018). Stop Stunting dengan Konseling Gizi. Jakarta: Penebar PLUS+. 


\section{STRADA Jurnal Ilmiah Kesehatan}

DOI: $10.30994 /$ sjik.v9i2.536

ISSN: 2252-3847 (print); 2614-350X (online)

Vol.9 No.2 November 2020 Page.1797-1806

Reyes, H., Pérez-Cuevas, R., Sandoval, A., Castillo, R., Santos, J. I., Doubova, S. V, \& Gutiérrez, G. (2004). The family as a determinant of stunting in children living in conditions of extreme poverty: a case-control study. BMC Public Health, 4(1), 57. https://doi.org/10.1186/1471-2458-4-57

Santoso, M. V, Kerr, R. B., Hoddinott, J., Garigipati, P., Olmos, S., \& Young, S. L. (2019). Role of Women's Empowerment in Child Nutrition Outcomes: A Systematic Review. Advances in Nutrition, 10(6), 1138-1151. https://doi.org/10.1093/advances/nmz056

Setiawan, E., Machmud, R., \& Masrul, M. (2018). Faktor-Faktor yang Berhubungan dengan Kejadian Stunting pada Anak Usia 24-59 Bulan di Wilayah Kerja Puskesmas Andalas Kecamatan Padang Timur Kota Padang Tahun 2018. Jurnal Kesehatan Andalas, 7(2), 275. https://doi.org/10.25077/jka.v7i2.813

Sismulyanto, I Ketut Andika Priastana, Hyan Oktodia Basuki, Irwina Angelia Silvanasari, Nur Melizza, Dyah Pitaloka, ... Luluk Fauziah Januarti. (2017). Modul Deteksi Dini Tumbuh Kembang Balita dalam Keperawatan Komunitas. In Fakultas Keperawatan Universitas Airlangga. ID. 